\title{
Faktor-Faktor Yang Mempengaruhi Ruptur Perineum Pada Ibu Bersalin Normal di Rumah Sakit Bhayangkara Mappaouddang Makassar Tahun 2014
}

\author{
Lilis Candra Yanti \\ Sekolah Tinggi Ilmu Kesehatan Husada Mandiri Poso \\ Email : liliscandrayanti@gmail.com
}

\begin{abstract}
Background: Perineal rupture is a problem in labor and the second cause of bleeding after uterine atony. According to WHO in 2014 there were 2.7 million cases of Perineal Rupture in maternity mothers. Factors that can cause perineal rupture are parity, distance of birth, baby's weight, birth management is not as it should be, age, extraction, vacuum extraction, and episiotomy. Objective: For Factors Affecting Normal Perineal Rupture. Research Methods: This study is an analytic observational with a "cross sectional study" approach. The population, namely primigravida mothers who were treated in Bhayangkara Mappaouddang Makassar Hospital in 2014, amounted to 230 people. Sampling with purposive sampling technique amounted to 120 samples. Data using Chi-Square statistical test with $\mathrm{P}$ value $>0.05)$. Results: There was an effect of maternal age on normal perineal rupture (P-Value $=0.003$ $<0.05)$, there was an effect of infant birth weight on normal perineal rupture $(\mathrm{P}-$ Value $=0.003<0.05)$ ) and there is an influence of the recommended position to treat normal perineal rupture of primigravida mothers $(\mathrm{P}$-Value $=0.004<0.05)$. Conclusion: There is an effect of maternal age, birth weight and recommended position with normal perineal rupture.
\end{abstract}

Keywords: maternal age, baby's birth weight, , perineal rupture

\begin{abstract}
Abstrak
Latar Belakang : Ruptur Perineum merupakan salah satu masalah dalam persalinan dan penyebab kedua perdarahan setelah atonia uteri. Menurut WHO pada tahun 2014 terjadi 2,7 juta kasus Ruptur Perineum pada ibu bersalin. Faktor- faktor yang dapat menyebabkan terjadinya ruptur perineum adalah paritas, jarak kelahiran, berat badan bayi, pimpinan persalinan tidak sebaimana mestinya, umur, ekstrasi cunam, ekstrasi vakum, trauma alat dan episiotomi. Tujuan: Untuk Faktor-Faktor Yang Mempengaruhi Ruptur Perineum pada ibu bersalin normal Persalinan Normal. Metode Penelitian : Penelitian ini bersifat observasional analitik dengan pendekatan "cross sectional study". Populasi yaitu ibu dengan persalinan normal yang dirawat di RS Bhayangkara Mappaouddang Makassar Tahun 2014 berjumlah 230 orang. Pengambilan sampel dengan teknik purposive Sampling berjumlah 120 sampel. Data dengan menggunakan uji statistik Chi-Square dengan nilai $\mathrm{P}<0,05)$. Hasil:Terdapat pengaruh umur ibu terhadap Ruptur Perineum persalinan normal $(P$-Value $=0,003<0,05)$, terdapat pengaruh berat badan lahir bayi terhadap Ruptur Perineum persalinan normal $(P$-Value $=0,003<0,05)$. Kesimpulan: Ada pengaruh umur ibu dan berat badan lahir bayi dengan terjadinya Ruptur Perineum pada ibu bersalin normal.
\end{abstract}

Kata Kunci : umur ibu, berat badan lahir bayI, ruptur perineum 


\section{PENDAHULUAN}

Ruptur perineum adalah robekan obstetrik yang terjadi pada daerah perineum diakibatkan oleh ketidakmampuan otot dan jaringan lunak pelvik untuk mengakomodasi lahirnya fetus (1). Ruptur Perineum terjadi pada hampir semua persalinan pertama,dan tidak jarang juga pada persalinan berikutnya. Ruptur Perineum perlu mendapatkan perhatian karena dapat menyebabkan fungsi organ reproduksi wanita, sebagai sumber perdarahan, dan sumber atau jalan keluar masuknya infeksi, yang kemudian dapat menyebabkan kematian karena perdarahan atau sepsis (2).

Dampak dari terjadinya Ruptur Perineum pada ibu antar lain terjadinya infeksi pada luka jahitan dimana dapat merambat pada saluran kandung kemih ataupun pada jalan lahir yang dapat berakibat pada munculnya komplikasi infeksi kandung kemih maupun infeksi pada jalan lahir. Selain itu juga dapat terjadi perdarahan karena terbukanya pembuluh darah yang tidak menutup sempurna sehingga perdarahan terjadi terus menerus. Penatalaksanaan Ruptur Perineum yang kurang baik dapat menimbulkan infeksi sehingga dapat menjadi penyebab kematian ibu. Faktorfaktor yang menyebabkan terjadinya ruptur perineum adalah paritas, jarak kelahiran, berat badan bayi, pimpinan persalinan tidak sebaimana mestinya, umur, ekstrasi cunam, ekstrasi vakum, alat dan episiotomi (3).

Menurut data WHO pada tahun 2014 kejadian Ruptur Perineum pada ibu bersalin terjadi sebanyak 2,7 juta kasus. Dimana angka ini diperkirakan pada tahun 2050 akan mencapai 6,3 juta hal I I terjadi seiring dengan semakin tingginya bidan yang tidak mengetahui asuhan kebidanan dengan baik. (4). Di Amerika dari 26 juta ibu bersalin yang mengalami kasus ruptur perineum sebesar $40 \%$ diantaranya disebabkan karena kelalaian bidannya. Dan 20 juta diantaranya berasal dari ibu bersalin itu sendiri. (5).

Ruptur perineum disebabkan oleh beberapa faktor antara lain oleh faktor ibu sendiri (yang mencakup paritas, jarak kelahiran,dan berat badan bayi saat lahir), dan faktor riwayat persalinan yang mencakup ekstraksi cunam, ekstraksi vakum dan episiotomy (6).

Pada penelitian yang dilakukan oleh Suryani (2013) tentang faktor-faktor Yang berhubungan dengan ruptur perineum pada persalinan normal di Rumah Bersalin Atiah 
menemukan bahwa paritas dan berat badan bayi baru lahir merupakan faktor yang berhubungan dengan ruptur perineum pada ibu dengan persalinan normal (7).

Berdasarkan studi pendahuluan yang dilakukan di Rumah Sakit Bhayangkara Mappaoudang Makassar pada tahun 2014 di dapatkan ibu yang mengalami Ruptur Perineum sebanyak 230 orang dari 876 persalinan.Untuk mencegah timbulnya infeksi atau komplikasi lainnya pada masa nifas utamanya dengan ruptur pada perineum dapat dilakukan dengan peningkatan mutu pelayanan kesehatan antara lain perawatan perineum secara intensif.

\section{METODE}

Penelitian ini menggunakan rancangan observasional analitik dengan pendekatan cross sectional study dimana responden yaitu ibu yang bersalin normal di Rumah Sakit Bhayangkara Mappaouddang Makassar tahun 2014. Metode pengumpulan data melalui observasi langsung oleh peneliti terhadap pelaksanaan pertolongan persalinan normal dan kejadian ruptur perineum. Data dianalisis menggunakan uji statistik Chi-Square.

\section{HASIL}

\section{Tabel 1}

Distribusi frekuensi Ruptur Perineum pada ibu dengan persalinan Normal di RS Bhayangkara Mappaouddang Makassar Tahun 2014

\begin{tabular}{ccc}
\hline $\begin{array}{c}\text { Ruptur Perineum Pada ibu } \\
\text { primigravida }\end{array}$ & Frekuensi (f) & Presentase (\%) \\
\hline Ya & 84 & 70,0 \\
Tidak & 36 & 30,0 \\
Jumlah & 120 & 100,0 \\
\hline
\end{tabular}

Tabel 1. menunjukkan bahwa distribusi frekuensi ibu primigravida yang mengalami Ruptur Perineum persalinan normal adalah 84 orang $(70,0 \%)$ dan yang bukan ibu primigravida yang mengalami Ruptur Perineum persalinan normal adalah sebanyak 36 orang (30,0\%).

\section{Tabel 2}

Distribusi frekuensi Ruptur Perineum pada ibu dengan persalinan Normal berdasarkan Umur di RS Bhayangkara Mapaouddang Makassar Tahun 2014 


\begin{tabular}{ccc}
\hline Umur ibu & Frekuensi ( f ) & presentase (\% ) \\
\hline Risiko tinggi & 65 & 54,2 \\
Risiko rendah & 55 & 45,8 \\
Jumlah & 120 & 100,0 \\
\hline
\end{tabular}

Tabel 2 menunjukkan bawah distribusi frekuensi Ruptur Perineum persalinan normal berdasarkan umur ibu adalah yang berisiko tinggi sebanyak 65 orang ( 54,2\%) dan umur ibu yang berisiko rendah sebanyak 55 orang ( $45,8 \%$ ).

\section{Tabel 3}

Distribusi frekuensi Ruptur Perineum pada ibu dengan persalinan Normal berdasarkan berat badan lahir Bayi di RS Bhayangkara Mappaouddang MakassarTahun 2014

\begin{tabular}{ccc} 
Berat badan Lahir Bayi & Frekuensi (f) & Persentase (\%) \\
\hline Risiko tinggi & 74 & 61,7 \\
Risiko rendah & 46 & 38,3 \\
Jumlah & 120 & 100,0 \\
\hline
\end{tabular}

Pada Tabel 3 menunjukkan bahwa distribusi frekuensi Ruptur Perineum persalinan normal berdasarkan berat badan lahir bayi yang berisiko tinggi yaitu sebanyak 74 orang (61,7\%) dan pada berat badan lahir bayi risiko rendah yaitu 46 orang $(38,3)$.

Tabel 4

Pengaruh Ruptur pada ibu dengan persalinan Normal berdasarkan umur ibu di RS Bhayangkara Mappaouddang Makassar Tahun 2014

\begin{tabular}{|c|c|c|c|c|c|c|c|}
\hline \multirow[t]{3}{*}{ Umur Ibu } & \multicolumn{4}{|c|}{$\begin{array}{l}\text { Ruptur perineum persalinan normal } \\
\text { pada Ibu }\end{array}$} & \multirow[t]{3}{*}{ Total } & \multirow[t]{3}{*}{$\%$} & \multirow[t]{3}{*}{$P$-Value } \\
\hline & \multicolumn{2}{|c|}{ primigravida } & \multicolumn{2}{|c|}{ bukan } & & & \\
\hline & $\mathrm{f}$ & $\%$ & $\mathrm{f}$ & $\%$ & & & \\
\hline Risiko tinggi & 53 & 44,2 & 12 & 10,0 & 65 & 54,2 & \\
\hline Risiko rendah & 31 & 25,8 & 24 & 20,2 & 55 & 45,8 & 0,003 \\
\hline Jumlah & 84 & 70,0 & 36 & 30,0 & 120 & 100 & \\
\hline
\end{tabular}

Hasil analisis bivariat pada tabel 5 menunjukkan bahwa umur ibu yang berisiko tinggi mengalami Ruptur Perineum persalinan normal pada ibu primigravida sebanyak 53 orang $(44,2 \%)$ dan umur ibu resiko tinggi tapi bukan ibu primigravida sebanyak 12 orang $(10,0 \%)$ serta umur ibu yang berisiko rendah mengalami Ruptur Perineum persalinan normal pada ibu 
primigravida sebanyak 31 orang $(25,8 \%)$ dan umur risiko rendah tapi bukan ibu primigravida sebanyak 24 orang $(20,2 \%)$.

Berdasarkan hasil uji statistik dengan menggunakan Chi-square didapatkan P-Value sebesar $0,003<0,05$ yang menunjukkan ada pengaruh umur ibu dengan terjadinya Ruptur Perineum persalinan normal pada ibu primigravida.

\section{Tabel 6}

Pengaruh Ruptur Perineum pada ibu dengan persalinan normal berdasarkan berat badan lahir bayi di RS Bhayangkara Mappaouddang Makassar Tahun 2014

\begin{tabular}{|c|c|c|c|c|c|c|c|}
\hline \multirow[t]{3}{*}{$\begin{array}{l}\text { Berat badan } \\
\text { Lahir bayi }\end{array}$} & \multicolumn{4}{|c|}{$\begin{array}{l}\text { Ruptur Perineum Persalinan normal } \\
\text { pada ibu }\end{array}$} & \multirow{3}{*}{ Total } & \multirow{3}{*}{$\%$} & \multirow{3}{*}{ P-Value } \\
\hline & \multicolumn{2}{|c|}{ primigravida } & \multicolumn{2}{|c|}{ bukan } & & & \\
\hline & $\mathrm{f}$ & $\%$ & $\mathrm{f}$ & $\%$ & & & \\
\hline Risiko tinggi & 59 & 49,2 & 15 & 12,5 & 74 & 61,7 & \\
\hline Risiko rendah & 25 & 20,8 & 21 & 17,5 & 46 & 38,3 & 0,003 \\
\hline Jumlah & 84 & 70,0 & 36 & 30,0 & 120 & 100 & \\
\hline
\end{tabular}

Hasil analisis bivariate pada tabel 6 menunjukkan bahwa berat badan lahir bayi yang berisiko tinggi mengalami terjadinya Ruptur Perineum persalinan normal pada ibu primigravida sebanyak 59 orang $(49,2 \%)$, dan berat badan lahir bayi yang berisiko tinggi dan bukan ibu primigravida sebanyak 15 orang $(12,5 \%)$ serta berat badan lahir bayi yang berisiko rendah mengalami terjadinya Ruptur Perineum persalinan normal pada ibu primigravida sebanyak 25 $(20,8 \%)$ dan berat badan lahir bayi yang beresiko rendah serta bukan ibu primigravida sebanyak 21 orang $(17,5 \%)$.

Berdasarkan hasil uji statistik dengan menggunakan rumus Chi square didapatkan $P$-Value sebesar 0,003 < 0,05 yang menunjukkan ada pengaruh berat badan lahir bayi dengan terjadinya Ruptur Perineum persalinan normal pada ibu primigravida.

\section{PEMBAHASAN}

\section{Pengaruh umur ibu dengan terjadinya ruptur perineum Pada Ibu Bersalin Normal}

Pada dasarnya umur dapat mempengaruhi proses persalinan sehingga dapat dikatakan bahwa pada usia muda dan tua tidak dianjurkan untuk melahirkan dengan alasan menghindari terjadinya komplikasi seperti ruptur perineum dimana pada usia $<20$ organ - 
organ reproduksinya wanita belum sempurna secara keseluruhan serta perkembangan kejiwaannya belum matang dalam menjalani proses persalinan sedangkan kehamilan diatas 35 tahun memiliki resiko tinggi untuk kehamilan dan persalinan (8)

Dari hasil penelitian ini diperoleh paling banyak ibu dengan umur beresiko tinggi yang mengalami rupture perineum. Penelitian ini sejalan dengan penelitian yang dilakukan oleh Marhamah, (2017) dimana persentase kejadian rupture perineum pada ibu bersalin lebih besar terjadi pada Umur beresiko ( $<20$ tahun dan> 35 tahun) yaitu 29 ibu (76,3\%) dari 86 ibu bersalin, sedangkan paling sedikit terjadi pada usia tidak beresiko (20-35 tahun), yaitu sebanyak 23 ibu (47,9\%) dari 86 ibu bersalin dengan umur tidak beresiko. (9)

Hasil penelitian lain yang didapatkan sesuai dengan teori dan penelitian terdahulu yaitu ibu bersalin yang berumur $<20$ tahun dan $>35$ tahun lebih cenderung terjadi ruptur perineum dibandingkan pada ibu yang berumur antara 20-35 tahun hal ini disebabkan karena pada umur $<20$ tahun organ-organ reproduksi belum siap dan sempurna untuk mengalami proses persalinan serta otot-otot daerah perineum yang kaku dan tidak elastis sehingga pada saat terjadi proses persalinan maka vagina akan mudah sekali terjadi ruptur dan pada umur $>35$ tahun organ reproduksi telah mengalami kemunduran. Sedangkan pada usia 20-35 tahun dimana organ-organ reproduksi sudah matang dan siap untuk terjadinya proses persalinan selain itu status emosionalnya juga lebih stabil dan lebih kooperatif ketika diajak berkomunikasi pada saat persalinan berlangsung. (10).

Hasil penelitian ini juga sejalan dengan penelitian yang dilakukan oleh Netty (2013) di BPM.S.Noer Aini yang menyatakan bahwa terdapat hubungan yang bermakna antara kejadian Rupture Perineum dengan umur ibu. (11) Pada usia dibawah 20 tahun fungsi reproduksi seorang wanita belum berkembang dengan sempurna sedangkan pada usia >35 tahun fungsi reproduksi seorang wanita sudah mengalami penurunan dibandingkan fungsi reproduksi normal. Umur $20-35$ tahun adalah kurun reproduksi sehat, alat-alat reproduksi sudah matang dan ibu sudah siap menghadapi persalinan, terjadi kesiapan dalam hal mempelajari sesuatu atau dalam menyesuaikan dengan keadaan tertentu, misalnya menghadapi persalinan. (12) 


\section{Pengaruh pengaruh berat badan lahir bayi dengan terjadinya ruptur perineum Pada Ibu Bersalin Normal}

Berat badan lahir bayi adalah berat badan pada saat bayi lahir dan berat badan lahir bayi sangat mempengaruhi proses persalinan kala II. Pada janin yang mempunyai berat lebih dari 3500 gram memiliki kesukaran yang ditimbulkan dalam persalinan adalah karena besarnya kepala atau besarnya bahu. Bagian paling keras dan besar dari janin adalah kepala,sehingga besarnya kepala janin mempengaruhi berat badan janin. Oleh karena itu sebagian ukuran kepala digunakan Berat Badan( BB) janin. Kepala janin besar dan janin besar dapat menyebabkan laserasi perineum (13).

Pada penelitian yang dilakukan oleh Wahyu Lestari pada tahun menujukkan ibu yang memiliki berat badan bayi $>3500$ gram sebanyak 52,9\% mengalami ruptur perineum sedangkan pada ibu yang memilki berat badan bayi 2500-4000 gram ditemukan sebanyak $47,1 \%$ mengalami ruptur perineum. Hasil analisis statistik dengan menggunakan uji chi square test diperoleh nilai $\mathrm{p}=0,001<0,05$ hal ini berarti ada pengaruh berat badan lahir bayi terhadap ruptur perineum pada ibu bersalin.

Berat badan bayi lahir normal antara 2500 gram - 4000 gram, yang diperoleh dari hasil penimbangan 24 jam pertama kelahiran. berat badan bayi baru lahir dapat mempengaruhi proses persalinan kala II, dimana semakin besar bayi yang dilahirkan akan meningkatkan resiko terjadinya ruptur perineum. Bayi besar adalah bayi yang begitu lahir memiliki bobot lebih dari 4.000 gram (14).

Berdasarkan hasil penelitian ini diperoleh sebagian besar ibu yang memiliki bayi dengan berat badan resiko tinggi (berat badan > 3500 gram) dan mengalami ruptur perineum merupakan ibu dengan persalinan primipara. Terjadinya ruptur perineum pada primipara disebabkan karena beberapa hal antara lain kelenturan jalan lahir / elastisitas perineum, mengejan yang tergesah-gesah dan tidak teratur serta berat badan bayi baru lahir. Penyebab ruptur perineum pada ibu multipara salah satunya adalah karena berat badan bayi baru lahir, kerapuhan perineum, asuhan sayang ibu yang kurang baik sehingga proses persalinan kurang terkendali seperti ibu kelelahan, mengejan sebelum waktunya sehingga partus menjadi macet / lambat. ruptur perineum yang terjadi pada primipara, tidak jarang juga terjadi pada multipara. Beberapa penyebab yang mengakibatkan terjadinya ruptur perineum pada paritas adalah partus presipitatus, mengejan terlalu kuat, edema dan kerapuhan pada 
perineum, kelenturan jalan lahir, persalinan dengan tindakan. Dan jika dilihat dari faktor resikonya, yang mempunyai resiko tinggi untuk terjadi ruptur perineum yaitu ibu bersalin primipara sedangkan ibu bersalin multipara mempunyai resiko rendah terjadi ruprtur perineum. (1).

\section{KESIMPULAN}

Dari hasil penelitian ini dapat disimpulkan faktor-faktor yang mempengaruhi terjadinya Ruptur Perineum pada ibu dengan persalinan normal yaitu faktor umur ibu dan berat badan bayi lahir.

\section{DAFTAR PUSTAKA}

1. Oxorn H. Ilmu Kebidanan : Patologi dan Fisiologi Persalinan. Yogyakarta : Yayasan Essentika Medica. 2010

2. Manuaba, Candradinata.. Gawat Darurat Obstetri Ginekologi Dan Obstetri Ginekologi Social Untuk Profesi Bidan. Jakarta : EGC. 2008

3. Carey, J. Ilmu Kesehatan Obstetri Patologi Reproduksi Edisi 2. Jakarta: EGC: 179-186. 2005

4. Hilmy, (2010). Rupture perineum. http://scribd.com

5. Heimburger,. The Essentials of Postpartum Care. Inggris: The New England Journal of Medicine. 2009

6. Manuaba. Ilmu Kebidanan, Penyakit Kandungan dan Keluarga Berencana Untuk Pendidikan Bidan. Jakarta : EGC. 2006

7. Suryani. Faktor-Faktor Yang Berhubungan Dengan Ruptur Perineum Pada Persalinan Normal Di Rumah Bersalin Atiah. Jurusan Kebidanan Poltekkes kemenkes Jambi. 2013

8. Wiknjosastro, H. 2008. Ilmu Kandungan. Edisi 2. Jakarta : EGC . 2008

9. Marhamah, Mera. Faktor-Faktor yang Berhubungan dengan Kejadian Ruptur Perineum pada Persalinan Pervaginam di Puskesmas Kecamatan Pasar Minggu .Jakarta Selatan. 2017

10. Siswosudarmo, R. Obstetri Fisiologi. Pustaka Cendekia. Yogyakarta. 2008

11. Netty. Faktor-Faktor yang Berhubungan dengan Kejadian Ruptur Perineum, Karya Tulis Ilmiah, BPM S.Noer Aini, Jakarta Selatan. 2013

12. Wiknjosastro, H. Ilmu Kebidanan.3 ed. Jakarta: YBPSP; 2007.

13. Mochtar, Rustam. Sinopsis obstetri : obstetri operatif, obstetri sosial, jilid 2. Jakarta: EGC. 2008

14. Dewi, Vivian Nanny Lia., Sunarsih, Tri. Asuhan Kebidanan Ibu Nifas. Jakarta : Salemba Medika. 2011 